\title{
The Role of Women in Smallholder Plantations of Oil Palm
}

\author{
Purwaningsih $^{1}$, Dusadee Ayuwat ${ }^{2}$, Jaggapan Cadchumsang ${ }^{3}$ \\ \{purwaning02@gmail.com ${ }^{1}$, dusayu@kku.ac.th ${ }^{2}$ \} \\ Khon Kaen University, Thailand ${ }^{1,2,3}$
}

\begin{abstract}
Oil Palm plantations provide job opportunities. The workers in the oil palm plantation consist of men and women. Involvement of women in oil palm plantations to help increase the amount of income gained by the farmer's household. However, the impact of women's involvement in oil palm plantations is causing vulnerabilities for women. The majority of women in palm oil plantations are related to the upkeep section, such as the activities of cultivating, picking up the fallen palm fruit, spraying, and clearing weeds. Women tend to work to be due to economic reasons. This paper will discuss the role of women on individually owned land of households and their problems. The location of the study was held in East Kutai Regency, East Kalimantan Province. The methods of research used qualitative research methods for exploring and understanding the social problem of women in smallholder plantations. The results show that women working in oil palm plantations, especially smallholders undergo two roles as a housewife and a farmer's wife.
\end{abstract}

Keywords: Women, Independent Smallholder, The Role.

\section{Introduction}

Palm oil is a commodity plant that expanded plantation ranks first in Indonesia [1]. Expansion of oil palm plantations also occurred in the province of East Kalimantan, including in East Kutai regency. Expansion of oil palm plantations in East Kutai district is at least implemented by three actors, namely large-scale plantations by a private company, cooperation between the company and the farmers (Nucleus estate scheme/dependent Smallholders), and independent smallholders.

On oil palm plantations are involved men and women as workers. The oil palm plantation system weakens the position of women [2]. Therefore, in women's oil palm plantations include vulnerable groups. The vulnerability of women in oil palm plantations was showed with evidence that (1) in the subdivisions of the oil palm plantation system, despite a family-based division mechanism but its ownership was named for the husband, not on behalf husband and wife (2) some jobs in oil palm plantations are identified as women's work (such as fertilizing, spraying). Women who work as labor of oil palm farming are households who have the type of activities to give Palm fertilizers, take the fallen palm fruit, poison the pest of the palm, and weeding the grass around Palm trees [3].

The study on the role of women in oil palm plantations is important because palm plantations based on the different categories of managers. There is a chance that the female 
roles in palm plantations have variation. This paper will be focused on studying the role of women in the independent oil palm smallholdings.

Normatively in Indonesian society applies that males in households occupy positions as household heads while women in the position of wives have a role of housewives. The head of the household has the main breadwinner [4]. In fact, a housewife is required to be the person in charge of household affairs from childbirth, nurturing that raising her children. Nevertheless, housewives in the village are accustomed to have the role of an additional breadwinner and a living point for poor households.

Role theory has been used effectively by researchers in psychology, social psychology, sociology, organization behavior, and human resource management since the early 1930s. Roles play an important part in social structure and roles have been recognized as central to understanding women behavior in farmer households. An important contribution of role theory is as the basis for job descriptions as well as for specifying women expectations.

Differences in the role of women and men in households established by the community based on the nature of women and men deemed appropriate according to norms, customs, beliefs or societal habits. Considering the position of women and men in the household, it is often found that women or wives have their social network. Through his social network, wives have a level of opportunity to pursue a certain position in its social network structure.

The division of duty refers to the pattern of role in the household. Husband and wife have their own duties. Power and division of work is the most fundamental in the households. The pattern of relationship between husband and wife can be understood in mastering valuable resources such as wealth, money, skills, and information.

The distributed domestic Division of labor that is the responsibility of the wife or woman affects the productive role of women or wives. They are considered reserve workers and for married women, productive work is regarded as a second job. In other words, women's workplace is considered an additional breadwinner. Women worked because of: (1) to increase family income; (2) to alleviate boredom or fill free time; (3) to get a better status; (4) to develop themselves; (5) because of failures in marriage; (6) in order not to depend on the husband economically; (7) for wanting to utilize expertise and experience [3].

\section{Research Methods}

This research uses qualitative methods, which are methods to explore and understand the meaning of social problems, in this case, is the role of women in the independent oil palm plantation and the households. Primary Data is collected through in-depth interviews and observations. Observation is a way of collecting data or information done by systematically recording the phenomena that occur in the field.

Secondary data is collected through our reviews of various research reports, journal articles, books, and other supporting documents. The research field is held in East Kutai district, Province of East Kalimantan, the reason chose this regency because East Kutai Regency is the largest trans-migrant placement area 624 households or $47.5 \%$ of the total placement of trans-migrants in East Kalimantan Province during the Era of Autonomy. The East Kutai Regency has the area of palm oil plantation more than 5 million hectare. 


\section{Results and Discussion}

Administrations East Kutai Regency has 18 sub-districts, 132 villages, and 2 urban villages. The width of East Kutai regency is $35,747.50 \mathrm{~km}^{2}$ or $17 \%$ of the total area of East Kalimantan province. The boundaries of East Kutai Regency are (1) North: Talisayan and Kelay sub-districts (Berau Regency); (2) South: North Bontang sub-district (Bontang Municipality), Marang Kayu sub-district, Muara Karam sub-district (Kutai Kartanegara Regency; (3) the East: Makassar Strait and Sulawesi Sea; (4) the West: Kembang Janggut and Tabang sub-districts (Kutai Kartanegara Regency).

One of the potentials owned by the East Kutai Regency is the land developed for agribusiness commodities, such as oil palm plantations. The area of palm oil plantation in East Kutai Regency is 5,082,353.78 hectares with productivity of about 517,300.37 kg/hectare[5]. Palm oil is one of the plantation sectors that play an important role in Indonesia's economic activities.

East Kutai Regency, as administratively conveyed, has 132 villages. Some of the villages were once transmigration locations. Related to the Transmigration program, government policy contains the criteria of transmigration participants are a family consisting of husband and wife. The policy then becomes an obstacle for single women or widows to have the opportunity to get land on their behalf. Particularly for transmigration participants with a pattern of oil palm plantations that oblige a spouse, then automatically ownership of the land to belong to the head of the family or husband. The position of the wife as a husband companion contained in the principle of unknowingly Empowerment Family Welfare is also adopted in the Transmigration program. Nevertheless, trans-migrant wives remained involved in plantations, from land clearing, nursery, care, to harvesting, but because the construction that woke up was the wife as a husband companion, the position of the wife was seen as helpful in the garden. The criteria of the transmigration participant provisions indirectly indicate that there is a transmigration program policy resulting in the marginalized on unmarried women or widows from access to the opportunity own palm plantation land.

Oil palm plantations have two phases, namely the phase before generating ( $0-4$ years) and the phase of after generating (above 4 years). In the first phase of activities in oil palm plantations include clearing, breeding, and planting of palm seedlings until the management of oil palm crops before producing (usually up to 4 years). While in the second phase of activities in the oil palm plantations include fertilization, plant maintenance, harvesting.

The governance of palm oil plantations is classified into three models, namely management with large scale plantations; Garden system; and the system of mixed plantations (petty cultivation). Firstly, the large-scale plantation model has the characteristics of the perpetrator is an investor as the financier and does not grow directly to plant palm oil. The character of the system of large oil palm plantation companies in the area that reaches more than 25 hectares, has orientation for market needs and profits, capital intensive, and plants developed is the oil palm plants that sell hard in the Market. Secondly, the garden system model. The perpetrators of the garden system are working directly to plant palm oil crops; land area of fewer than 10 hectares; have an orientation to suffice household needs; labor dense; plants that are already known and able to meet household needs. Thirdly, the petty cultivation model is plantation governance with a mixed-plant character planted for subsistence and plant crops for trade; in this case, it is oil palm. On the plantation model of agricultural products, orientation is not only own consumed but partly sold to the market.

My paper aims to discuss the role of women in the independent palm oil smallholding. As a farmer's wife, women in the palm farmer households are involved in the process of 
managing family gardens. A glimpse of their work in the palm groves is as good as her husband because they share their duties evenly.

In the activity of fertilizing, a wife or woman sows around a plant and a husband or a man transporting fertilizer in bulk. Women have considerable involvement in oil palm production. This means that the participation of women in palm oil plantations adds to their workload as a housewife. The label wife of husband companion' in turn brings women got to a double burden for having to help the husband in the palm oil plantation.

Women's activities in oil palm plantations are related to the initial process of palm planting, treating palm oil, harvesting palm, selling palm oil crops. Women tend to be involved in oil palm plantations when the palm oil trees are still small 4-5 years old. Activities commonly done by women in the palm plantation is clearing the land, doing palm breeding, planting palm seedlings, cultivating, spraying. But when palm starts to bear fruit, women tend to be seldom seen in the garden than men. Nevertheless, most women hold and manage the proceeds of palm oil.

The powerful system of the embedded patriarchy resulted in the householder's women not likely to be involved in meetings held at night. For safety reasons for women, men ask women to stay home. Besides, the male farmers still hold the value that the primary livelihoods support for the family is a male responsibility. Nevertheless, there are some of the farmer households, who have a more balanced cultural background between men and women, working together in independent oil palm plantations. Women are also involved in agricultural activities in the garden around the house to help fulfil daily necessities, such as planting vegetables or planting medicinal plants.

As Wives or housewives, most of them do household chores, such as cooking, washing, caring for children, and other home works. Relationships between family members can be said to be egalitarian, it is evident from the way they communicate, as most of the wives of palm farmers show themselves confident when communicating in front of their husbands, showing no shame or fear of the wrong Talk. That is, in the family, there is freedom of speech.

For a wife or woman, her involvement in the oil palm plantation is not the burden, but rather as a form of cooperation in the family. Some informants give recognition that the participation of wives or women in plantations when they have free time. If they have little children, then, the wives or women do not have to work in the garden. In general, the wives of oil palm farmers or women woke up early more than her husband to prepare breakfast for children and husbands, then, she provides food for brought to the palm oil garden. From here it can be noted that women have a longer working time than her husband. On average the wife of farmers or women on oil palm plantations in East Kutai has the freedom to organize, such as to follow the activities of regular social gathering and Yasin recitation.

On the other hand, it is not uncommon for women to be more dangerous in terms of health impacts, such as spraying pesticides. This indication reflects that safety and safety standards for women are relatively low.

Palm oil plantations can cause women to work for long periods. Housework is generally done by women or wives. Although wives help husbands work in the garden, the involvement of men or husbands helps wives to do the housework quite rarely. The average female or wife works in the palm oil plantation for about 5 hours but that's not every day. Women's insight into oil palm plantations tends to be limited, as they are seldom involved in meetings, training, and other activities related to palm oil. 


\section{Conclusion}

Jobs in oil palm plantations are tend to distinguish gender. Men generally get a job that requires physical work. However, because of the high harvest target, they depend on the wife or woman and the family as workers. As a result, female labor contributions tend to be invisible and uncompensated.

Women on oil palm plantations tend to show interest in getting involved in oil palm plantation activities. They want to play a role to increase garden productivity. However, the structure is an obstacle to them. As women are being attached to a standard role as a farmer's wife and mothers are demanding to stay home, prepare food for husbands, and parenting, the imagery of women's social-constructed roles tends to further strengthen forms. The injustices experienced by women, especially in independent palm oil plantations.

\section{References}

[1] E. B. Yulian, A. H. Dharmawan, E. Soetarto, and P. Pacheco, "Dilema Nafkah Rumahtangga Perdesaan Sekitar Perkebunan Kelapa Sawit di Kalimantan Timur," Jurnal].[Internet]. J. Sosiol. Perdesaan, vol. 5, no. 3, pp. 242-249, 2017.

[2] A. Surambo et al., "Sistem perkebunan kelapa sawit memperlemah posisi perempuan," Bogor Lap. Penelit. Sawit Watch dan Solidar. Peremp., 2010.

[3] U. Musallamah and Y. Yoserizal, "Studi Tentang Buruh Tani Perempuan Di Desa Sukamaju Kecamatan Singingi Hilir Kabupaten Kuantan Singingi.” Riau University, 2017.

[4] T. Susilowat, "Peran serta wanita dan anak-anak dalam usaha meningkatkan penghasilan rumah tangga di Desa Marta Singa, Kabupaten Cirebon," 1998.

[5] BPS/ Central Bureau of Statistic, Kabupaten Kutai Timur dalam Angka 2017. 2017. 